\title{
Penyuluhan Tentang Bermedia Sosial yang Baik Bagi Siswa MA Nurut Tauhid Lumajang
}

\author{
Rio Febriannur Rachman ${ }^{1)}$, Salman Alfarisi ${ }^{2)}$, Muhammad Fahrur Rozi ${ }^{3)}$ \\ Muamar Roviyanto ${ }^{4)}$ \\ 1,2,3,4) Institut Agama Islam Syarifuddin Lumajang \\ riofrachman21@gmail.com
}

\begin{abstract}
ABSTRAK: Keberadaan media sosial berbasis internet menjadi tantangan tersendiri bagi kehidupan manusia sehari-hari. Ia seakan pisau bermata dua, punya sisi positif dan negatif. Khususnya, bagi para pemuda yang merupakan generasi penerus bangsa. Pengabdian kepada masyarakat ini menjadikan para siswa, sebagai kelompok pemuda, di Madrasah Aliyah atau MA Nurut Tauhid sebagai sasaran. Pengabdian yang dilakukan berupa penyuluhan tentang bermedia sosial yang bijak. Metode yang dilakukan adalah memberi ceramah intensif tentang empat hal pokok terkait media sosial. Pertama, menggunakan media sosial secara cermat. Kedua, dampak positif media sosial. Ketiga, dampak negatif media sosial. Keempat, waspada kecanduan media sosial. Penyuluhan dilaksanakan empat hari berturut-turut kepada 30 siswa kelas IX, tiap hari 45 menit. Sehingga, para siswa tidak bosan dan mendapat materi secara efektif. Hasilnya, para siswa antusias menerima materi yang diberikan dan diskusi berjalan dengan baik. Harapannya, para siswa bias bermedia sosial secara bijak dan dapat menyebarkan wawasan tentang bagaimana bermedia sosial secara baik pada orang-orang di sekitar.
\end{abstract}

Kata kunci: Penyuluhan, Media Sosial, Pemuda, Dampak Internet

ABSTRACT: The existence of internet-based social media is a challenge for everyday human life. It is like a double-edged knife, has both positive and negative sides. In particular, for young people who are the nation's next generation. This community service has targeted students, as a youth group, in the Madrasah Aliyah Nurut Tauhid. The service, in the form of counseling, is regarding how to use social media wisely. The method used is to give intensive lectures on four main issues related to social media. First, how to use social media well. Second, the positive impact of social media. Third, the negative impact of social media. Fourth, be aware of social media addiction. Counseling carried out four days, each 45 minutes, to 30 students of IX class. The result, students enthusiastically accepted the material provided and the discussion went well. The hope, students can use social media wisely and spread the insight to the other people around them.

Keywords: Counseling, Social Media, Youth, Internet Impact

\section{PENDAHULUAN}

Media sosial berbasis internet sudah sukar dilepaskan dari kehidupan masyarakat (Fuchs, 2017). Semua elemen masyarakat perlu paham dengan media online agar tidak ketinggalan zaman (Bariyyah \& Permatasari, 2017). Ada banyak platform media sosial yang akrab di tengah masyarakat, antara lain, facebook, Instagram, twitter, dan Youtube. Media sosial juga sudah mulai dekat dengan kehidupan para pemuda (Madden Dkk, 2013). Bagaimana pun juga, internet sudah makin menjalar ke desa-desa dan makin menghidupkan eksistensi media sosial baik di kota maupun pelosok. 
Kecepatan media sosial memotret dan menyebarkan informasi sukses menggantikan peranan media massa konvensional, dan menjadi pilihan masyarakat belakangan ini (Watie, 2011).

Media sosial membuat orang-orang merasa memiliki memiliki media sendiri (Rachman, 2017). Ruang penyebaran kabar, jalur sosialisasi, dan kanal berita makin luas (Fitriani, 2017). Di masa lampau, untuk memroduksi informasi perlu modal banyak guna membangun stasiun radio maupun televisi. Saat ini, bermodal kuota internet dan akun media sosial, seseorang bisa membuat konten dan menyebarkannya. Media sosial sudah sukses menjadi jalur penguat eksistensi diri (Cahyono, 2016).

Bertolak dari makin sentralnya peran media sosial di masyarakat, termasuk di kalangan para pemuda, memberikan pemahaman tentang bagaimana bermedia sosial yang bijak perlu diberikan (Salleh Dkk, 2017). Sasarannya, para pemuda, misalnya bagi mereka yang duduk di bangku sekolah. Oleh sebab itu, pengabdian masyarakat dalam bentuk "Penyuluhan Tentang Bermedia Sosial Yang Baik Bagi Siswa MA Nurut Tauhid Lumajang" dilaksanakan.

MA atau Madrasah Aliyah adalah lembaga pendidikan yang berbasis agama Islam. Sehingga, para lulusannya, selain memiliki wawasan pengetahuan umum, diharapkan pula punya ilmu agama yang dapat bermanfaat di masyarakat (Ikhwan, 2017). Yang pada gilirannya, mereka juga merupakan agen dakwah di masyarakat. Maka itu, dengan pembekalan mengenai media sosial yang mumpuni, mereka nantinya juga bisa menyebarluaskan apa yang sudah didapatkan pada khalayak luas. Sementara itu, MA Nurut Tauhid, tempat penyuluhan ini dilakukan, merupakan lembaga pendidikan yang cukup besar, populer, dan berdiri di lokasi yang strategis.

Metode yang dilakukan dalam penyuluhan ini adalah ceramah secara langsung pada salah satu rombongan belajar di MA Nurut Tauhid. MA Nurut Tauhid berada di Desa Wonorejo, Kecamatan Kedungjajang, Kabupaten Lumajang, Jawa Timur, di tepi Jalan Raya Lumajang-Jember. Visinya, menciptakan generasi berakhlakul karimah dan berfikir ahlussunnah waljama'ah. Misinya, pertama, mempersiapkan siswa siswidengan memiliki penguasaan di bidang akademikdan non akademik. Kedua, untuk melanjutkan kejenjang yang lebih tinggi, menjadikan sifitas akademik MA Nurut Tauhid. Ketiga, sebagai figur/teladan bagi masyarakat madani di era globalisasi. Tujuannya, pertama, meningkatkan prestasi non akademik, dengan mengembangkan potensi,minat,dan bakat siswa. Kedua, menjadikan MA Nurut Tauhid wonorejo kedungjajang lumajang sebagai madsrasah rujukan. Ketiga, meningkatkan kualitas lulusan yang memiliki prestasi akademik tinggi.

\section{PERMASALAHAN}

Berdasarkan analisis terhadap kondisi yang ada, terdapat beberapa permasalahan yang melatarbelakangi kegiatan "Penyuluhan Tentang Bermedia Sosial Yang Baik Bagi Siswa MA Nurut Tauhid Lumajang” adalah para siswa perlu mendapatkan materi 
tentang bermedia sosial yang baik serta para siswa di sekolah Islam mesti punya wawasan memadai sehingga di masa datang bisa menjadi agen dakwah di masyarakat.

\section{METODE PELAKSANAAN}

Kegiatan pengabdian masyarakat yang bertajuk "Penyuluhan Tentang Bermedia Sosial Yang Baik Bagi Siswa MA Nurut Tauhid Lumajang” dilaksanakan secara bertahap sesuai dengan jadwal yang telah dibuat dalam Rencana Tindak. Secara umum, ada tiga pokok kegiatan yang dilaksanakan sekitar sebulan penuh pada Februari 2020 ini. Pertama, perencanaan dan penyusunan materi. Dalam tahapan ini, diputuskan untuk memilih MA Nurut Tauhid, salah satu lembaga pendidikan Islam yang besar dan berlokasi strategis di Lumajang. Dipilih pula salah satu rombongan belajar yang dijadikan sasaran penyuluhan, yakni, kelas XI MA Nurut Tauhid, berjumlah 30 siswa.

Tabel 1. Tahap pelaksanaan kegiatan

\begin{tabular}{llll}
\hline No & \multicolumn{1}{c}{ Kegiatan } & \multicolumn{1}{c}{ Waktu Pelaksanaan } \\
\hline 1 & $\begin{array}{l}\text { Perencanaan dan penyusunan } \\
\text { penyuluhan }\end{array}$ & materi & 3 sampai 6 Februari 2020 \\
\hline 2 & Survey lokasi & 8 sampai 9 Februari 2020 \\
\hline 3 & Pelaksanaan kegiatan penyuluhan & 24 sampai 27 Februari 2020 \\
& & Tiap pertemuan per hari selama 45 menit. \\
\hline
\end{tabular}

\section{PELAKSANAAN}

Pelaksanaan penyuluhan secara langsung pada para siswa dilakukan dalam empat hari berturut-turut pada 24, 25, 26, dan 27 Februari 2020. Pada hari pertama, secara umum dijelaskan tentang media sosial. Termasuk, empat platform yang paling banyak dipakai oleh masyarakat Indonesia, Facebook, Twitter, Instagram, dan Youtube. Berikut adalah materi penyuluhan yang dilaksanakan di MA Nurut Tauhid. Tentu saja, materi yang disampaikan ini merupakan modul pengantar tekstual saja. Pada faktanya, di sesi diskusi terdapat elaborasi lebih lanjut berkenaan dengan materi tersebut.

\section{Bagaimana menggunakan media sosial secara cermat (materi 24 Februari 2020)}

Pentingnya menyaring teman. Jangan sembarangan berkoneksi dengan orang lain yang tidak dikenal. Hampir semua media sosial memiliki fitur untuk menfilter siapa saja yang bisa berteman dan mengikuti pengguna. Contohnya, di Instagram, ada fitur private account. Artinya, akan pembatasan informasi yang bisa diakses publik terkait pengguna. Pasanglah foto profil yang tidak berlebihan sehingga tidak mengundang hal-hal yang tidak diinginkan. Selanjutnya, foto-foto yang dibagikan di akun media sosial juga tidak perlu berlebihan. Sebab, bisa jadi ada orang-orang tak bertanggung jawab yang memakai foto dari akun media sosial pengguna, untuk hal-hal yang tidak baik (Rifauddin \& Halida, 2018).

Pastikan memikirkan secara bijak konten apa yang ingin dibagikan di akun media sosial. Jangan asal mengetik, karena bisa terkena pasal di UU ITE (Magdalena, 
2013). Jangan asal membagikan konten karena bisa berpotensi menyinggung orang lain. Sebelum membagikan konten, pikirkan apa yang hendak dibagikan, apa tujuannya, dan apa dampaknya. Memberikan informasi tentang identitas diri harus dipertimbangkan. Jangan asal mempublikasikan nomor telepon, alamat rumah, dan atau informasi tentang data diri lainnya. Karena bisa membuka celah kejahatan orang lain yang punya niat buruk.

\section{Dampak positif media sosial (materi 25 Februari 2020)}

Media sosial bisa menjadi sarana penyimpanan informasi dan dokumentasi. Melalui situs-situs yang terhubung dengan akun media sosial, pengguna dapat mengakses informasi secara lebih cepat dan mudah (Ariel \& Avidar, 2015). Pada perkembangannya, media sosial juga membantu pengguna mengakses informasi tentang keluarga atau kerabat serta sahabat lama. Dalam konteks ini, media sosial telah menjadi sarana silaturahmi. Media sosial juga memerkuat mekanisme ekonomi melalui fitur-fitur belanja online (Rachman, 2019). Usaha Mikro Kecil Menengah atau UMKM bisa memiliki kesempatan yang lebih luas dalam memasarkan produk (Saputra \& Sari, 2019). Terlebih saat ini sudah banyak aplikasi layanan jasa lainnya yang makin membuka luas lapangan pekerjaan. Artinya, media sosial turut mengerek peluang kesejahteraan masyarakat.

Media sosial juga dapat menjadi sarana dakwah keagamaan. Agama apa pun jua, termasuk Islam. Penggunaan media sosial merupakan jalan penyebaran informasi religi di era milenial kekinian (Ghofur, 2019). Ada banyak para penceramah yang justru terkenal setelah eksis di dunia maya virtual terlebih dahulu dibandingkan di dunia nyata. Dengan kata lain, media sosial bisa menjadi cara pengembangan diri. Tidak hanya pendakwah, tapi juga profesi lainnya, semisal seniman, pengajar, dan lain sebagainya.

\section{Dampak negatif media sosial (materi 26 Februari 2020)}

Kebanyakan mengonsumsi media sosial bisa berdampak negatif, salah satunya membuat pengguna jadi tidak produktif (Nursikuwagus, 2020). Kecanduan internet dapat membuat pengguna bermasalah dengan fisik maupun mentalnya. Yang bersangkutan cenderung menjadi lebih malas dan tidak gampang bersosialisasi di masyarakat. Pengguna semacam itu ujung-ujungnya akan menjadi stress atau tertekan.

Di sisi lain, media sosial belakangan ini menjadi sarang berita palsu atau hoax. Orang yang terjebak dalam berita palsu atau informasi yang menyesatkan otomatis akan ikut tersesat. Apalagi, bila yang bersangkutan ikut menyebarkan kabar yang tak benar tersebut. Media sosial juga dapat menjadi sarana kejahatan, persekusi, fitnah, maupun sikap mengumbar kejelekan pihak lain (Taufani \& Karim, 2019). Padahal, tingkah laku tersebut jelas tidak baik dan bahkan sebagian bisa masuk dalam kategori kriminal. Oleh sebab itu, semua kalangan harus bisa menahan diri saat menggunakan media sosial.

\section{Waspada kecanduan media sosial (27 Februari 2020)}

Hati-hati dalam menggunakan media sosial. Sebab, piranti ini bisa menyebabkan kecanduan. Bila sudah kecanduan, harus diatasi dengan cepat dan tepat demi 
menghindari berbagai masalah kejiwaan (Soliha, 2015). Setidaknya ada tiga hal yang bisa dilakukan untuk menghindari kecanduan media sosial. Pertama, menguatkan tekad untuk memerbaiki diri. Bila perlu, segera berhenti total. Kedua, kalaupun tidak bisa berhenti total, mulailah dengan langkah yang paling simpel, seperti membatasi waktu pemakaian media sosial. Bila biasanya menggunakan media sosial per hari lima jam, buatlah hanya per hari dua atau tiga jam. Ketiga, cobalah bangkitkan hobi yang seru tanpa gawai. Semua orang pasti memiliki hobi, antara lain, olahraga atau berkarya seni. Asahlah kembali hobi itu. Dengan demikian, aktifitas tidak selalu berhubungan dengan gawai dan media sosial. Luangkan waktu untuk melakukan aktivitas fisik yang bermanfaat. Bisa berupa mengunjungi teman lama atau kerabat jauh, memancing, mendaki gunung, beribadah, membuat kue kesukaan, dan lain sebagainya.

\section{HASIL DAN LUARAN}

Kegiatan penyuluhan bermedia sosial yang baik untuk para siswa MA Nurut Tauhid memberikan manfaat dan inspirasi bagi peserta yang ikut berpartisipasi. Para peserta tampak antusias mengikuti diskusi. Kemampuan pemateri menyampaikan pesan menjadi poin penting. Oleh sebab itu, seorang pemateri wajib memiliki bekal sebelum tampil di hadapan publik (Lucas, 2009). Pemateri meyakinkan peserta bahwa bermedia sosial harus bijak. Khususnya, bagi para pemuda yang duduk di sekolah Islam. Sebab, mereka merupakan agen dakwah keislaman di masa datang. Secara umum, semua materi diminati oleh peserta karena empat tema yang diajukan memang berdasarkan rumusan yang mendalam. Fokus penyuluhan adalah tentang media sosial yang memang sudah dekat dengan para peserta. Namun, mereka juga butuh informasi tentang bagaimana bermedia sosial yang baik. Mengingat, belakangan ini banyak kasus kejahatan yang melibatkan media sosial . Dengan adanya penyuluhan ini, para siswa bisa mendapat pengetahuan yang memadai tentang praktek menggunakan media sosial, khususnya facebook, Instagram, twitter, dan YouTube. Terlebih, para peserta juga diberi modul materi yang disampaikan pada penyuluhan, sebagai pengingat dan referensi mereka nantinya.

\section{KESIMPULAN}

Berdasarkan pelaksanaan kegiatan pengabdian kepada masyarakat ini, maka dapat disimpulakan bahwa:

1. Kegiatan pengabdian kepada masyarakat mengenai bermedia sosial yang bijak di MA Nurut Tauhid ini telah terlaksana dengan baik.

2. Kegiatan pengabdian kepada masyarakat mengenai bermedia sosial yang bijak pada siswa di MA Nurut Tauhid ini mendapat respon yang baik dari para peserta.

Kegiatan pengabdian kepada masyarakat serupa dapat dilakukan secara rutin di lokasi yang sama dengan rombongan belajar berbeda, misalnya, di kelas X atau XII. Bisa pula dilakukan dengan materi lanjutan tentang bermedia sosial bagi siswa. 


\section{DAFTAR PUSTAKA}

Angkupi, P. 2017. Kejahatan Melalui Media Sosial Elektronik Di Indonesia Berdasarkan Peraturan Perundang-Undangan Saat Ini. MIKROTIK: Jurnal Manajemen Informatika, 2 (1).

Ariel, Y., \& Avidar, R. 2015. Information, interactivity, and social media. Atlantic Journal of Communication, 23(1): p. 19-30.

Bariyyah, K., \& Permatasari, D. 2017. Pelatihan Pemanfaatan Media Online Dalam Layanan Bimbingan Konseling Bagi Konselor Sekolah Menengah Pertama Di Kabupaten Pamekasan Madura. Dedication: Jurnal Pengabdian Masyarakat, 1(1): p. 63-69.

Cahyono, A. S. 2016. Pengaruh Media Sosial Terhadap Perubahan Sosial Masyarakat Di Indonesia. Jurnal Publiciana, 9(1): p. 140-157.

Fitriani, Y. 2017. Analisis Pemanfaatan Berbagai Media Sosial Sebagai Sarana Penyebaran Informasi Bagi Masyarakat. Paradigma-Jurnal Komputer dan Informatika, 19(2): p. 148-152.

Fuchs, C. 2017. Social media: A critical introduction. California: Sage.

Ghofur, A. 2019. Dakwah Islam Di Era Milenial. Dakwatuna: Jurnal Dakwah dan Komunikasi Islam, 5(2): p. 136-149.

Ikhwan, A. 2017. Development Of Quality Management Islamic Education In Islamic Boarding School (Case Study Madrasah Aliyah Ash Sholihin). Al-Hayat: Journal of Islamic Education, 1(1): p. 91-117.

Lucas, S. E. 2009. The Art of Public Speaking 11th Edition. Boston: Mc. Graw Hill.

Madden, M., Lenhart, A., Cortesi, S., Gasser, U., Duggan, M., Smith, A., \& Beaton, M. 2013. Teens, Social Media, And Privacy. Pew Research Center, 21: p. 2-86.

Magdalena, M. 2013. UU ITE: Don't be the Next Victim! Jakarta: Gramedia Pustaka Utama.

Nursikuwagus, A., Hikmawati, E., Wisesty, U. N., Munggana, W., \& Mahayana, D. 2020. Kajian Saintifik Fenomena Adiksi Gadget dan Media Sosial di Indonesia. Jurnal Teknologi dan Informasi (JATI), 10(1): p. 25-39.

Rachman, R. F. 2017. Menelaah Riuh Budaya Masyarakat Di Dunia Maya. Jurnal Studi Komunikasi, 1(2): p. 206-222.

Rachman, R. F. 2019. Optimalisasi Media Digital Berbasis Kemaslahatan Umat dalam Program Pahlawan Ekonomi Surabaya. Iqtishoduna: Jurnal Ekonomi Islam, 8: p. 273-292.

Rifauddin, M., \& Halida, A. N. 2018. Waspada Cybercrime dan Informasi Hoax pada Media Sosial Facebook. Khizanah al-Hikmah: Jurnal Ilmu Perpustakaan, Informasi, dan Kearsipan, 6(2): p. 98-111. 
Salleh, M. A. M., Abdullah, M. Y. H., Salman, A., \& Hasan, A. S. A. 2017. Kesedaran dan pengetahuan terhadap keselamatan dan privasi melalui media sosial dalam kalangan belia. e-BANGI, 12(3): p. 1-15.

Saputra, M., \& Sari, N. 2019. Pelatihan Inovasi dan Pemasaran Produk Pada Kelompok Wanita Tani (KWT) Singkong di Pekon Tanjung Anom Kecamatan Ambarawa Kabupaten Pringsewu. Dedication: Jurnal Pengabdian Masyarakat, 3(1): p. 712.

Soliha, S. F. 2015. Tingkat Ketergantungan Pengguna Media Sosial Dan Kecemasan Sosial. Interaksi: Jurnal Ilmu Komunikasi, 4(1): p. 1-10.

Taufani, E. M., \& Karim, H. 2019. Ghibah Melalui Media Sosial dalam Identifikasi Proses Komunikasi. Islamic Education Studies: an Indonesia Journal, 1(1): p. $10-14$.

Watie, Errika. D. S. 2011. Komunikasi dan Media Sosial (Communications and Social Media). The Messenger, 3 (1): p. 69-75. 
Volume 4, Nomor 2, September 2020 